\title{
ANALISIS KUALITAS PELAYANAN TERHADAP KEPUASAN ANGGOTA PERPUSTAKAAN STIE MANDALA JEMBER
}

Oleh:

\author{
Hayatul Maspufah \\ Program Studi Manajemen \\ Sekolah Tinggi Ilmu Ekonomi Mandala Jember \\ Email: \\ ulfa@stie-mandala.ac.id
}

\begin{abstract}
ABSTRAK
Penelitian ini bertujuan untuk mengetahui peningkatan mutu kualitas layanan perpustakaan terhadap kepuasan anggota perpustakaan STIE Mandala Jember. Penelitian ini adalah penelitian kuantitatif dengan menggunakan tehnik pengumpulan data melalui kuisioner yang diisi oleh anggota perpustakaan. Tehnik pengambilan sampel menggunakan random sampling, dengan jumlah sampel sebanyak 40 responden, alat analisis yang digunakan adalah Regresi Linier Berganda dan Uji hipotesisnya menggunakan Uji $F$ dan Uji $t$. Berdasarkan hasil penelitian dapat disimpulkan bahwa tidak semua variabel kualitas layanan terbukti signifikan, terdapat tiga variabel yang tidak signifikan yaitu variabel keandalan, jaminan dan Empati, sedangkan variabel daya tanggap dan bukti fisik berpengaruh signifikan terhadap kepuasan anggota perpustakaan. Hasil Penelitian ini diharapkan akan menghasilkan formulasi strategi dalam peningkatan kualitas layanan perpustakaan STIE Mandala Jember, dalam upaya meningkatkan kepuasan terhadap anggotanya.
\end{abstract}

Keywords: Kualitas Layanan, Kepuasan Anggota.

\section{A. PENDAHULUAN}

Perpustakaan merupakan bagian dari kebutuhan yang harus dipenuhi didalam kehidupan terutama masyarakat pelajar, mahasiswa, dan kelompokkelompok tertentu untuk menunjang aktifitasnya. Namun kita menyadari bahwa sebagian masyarakat yang lain belum mendapatkan fasilitas dan layanan perpustakaan sebagaimana mestinya. Hal itu merupakan peringatan bagi semua pihak untuk segera membenahi, dan mengembangkan perpustakaan sebagai salah satu pusat informasi, ilmu pengetahuan, teknologi dan budaya dalam rangka meningkatkan kecerdasan bangsa meliputi kecerdasan spritual, kecerdasan intelektual, kecerdasan personal, kecerdasan emosional, dan kecerdasan sosial (Sutarno, 2006).

Perpustakaan dengan tugas dan fungsinya merupakan salah satu sumber informasi dan pembelajaran bagi seluruh anggotanya, dengan mempertimbangkan 
pentingnya keberadaan perpustakaan, maka didirikanlah perpustakaan di lingkungan perguruan tinggi dalam hal ini perpustakaan Sekolah Tinggi Ilmu Ekonomi Mandala Jember. Konsep dasar perpustakaan didirikan oleh lembaga untuk anggota perpustakaan diantaranya Mahasiswa, Dosen, serta para Karyawan dan didanai dengan dana dari lembaga.

Sebagaimana diketahui bersama perpustakaan merupakan layanan publik, untuk itu perpustakaan wajib memberikan pelayanan yang berkualitas yaitu layanan yang dapat memenuhi kebutuhan pengguna perpustakaan. Pelayanan perpustakaan merupakan aktivitas perpustakaan dalam memberikan jasa layanan kepada pengguna perpustakaan, khususnya kepada anggota perpustakaan. Melalui perpustakaan para anggotanya dapat untuk saling bertukar pikiran, menambah wawasan dan pengalaman serta merupakan nilai tambah dalam mengembangkan pola kehidupan.

\section{Rumusan Masalah}

Perpustakaan merupakan jantung daripada sebuah perguruan tinggi, serta merupakan pusat penyedia layananan terhadap mahasasiswa, dosen bahkan karyawan yang membutuhkan beberapa informasi mengenai buku penunjang dalam pembelajaran, oleh karena itu perpustakaan harus lebih meningkatkan kualitas layanannya dan diharapkan agar pelanggan akan terpuaskan, karena kepuasan pelanggan merupakan salah satu alasan pelanggan untuk tetap loyal kepada penyedia jasa.

Berdasarkan latar belakang di atas, maka rumusan masalah dalam penelitian ini adalah:

1. Apakah variabel Daya tanggap (responsiveness), Keandalan (reliability), Jaminan (assurance), Empati (empathy), Bukti fisik (tangible) berpengaruh terhadap kepuasan anggota perpustakaan?

2. Variabel kualitas pelayanan manakah yang berpengaruh paling dominan terhadap kepuasan anggota perpustakaan?

\section{Tujuan Penelitian}

Penelitian ini memiliki beberapa tujuan yang hendak dicapai oleh peneliti. Berdasarkan rumusan masalah di atas, maka tujuan dalam penelitian ini adalah:

1. Untuk mengetahui variabel Daya tanggap (responsiveness), Keandalan (reliability), Jaminan (assurance), Empati (empathy), Bukti fisik (tangible) berpengaruh secara simultan dan parsial terhadap kepuasan anggota perpustakaan.

2. Untuk mengetahui variabel kualitas pelayanan yang berpengaruh paling dominan terhadap kepuasan anggota perpustakaan.

\section{B. KAJIAN PUSTAKA}

Definisi jasa menurut (Kotler, 1997) adalah Setiap tindakan atau kegiatan yang dapat ditawarkan oleh suatu pihak kepada pihak lain yang pada dasarnya tidak berwujud (intangible) dan tidak menghasilkan kepemilikan sesuatu. Berdasarkan definisi jasa tersebut diketahui bahwa di dalam jasa ada aspek 
interaksi antara pihak pelanggan dan pihak produsen jasa, meskipun pihak - pihak yang terlibat tidak menyadari. Jasa bukan merupakan suatu barang melainkan suatu proses atau aktivitas yang tidak berwujud. Produk jasa dapat berhubungan dengan produk fisik dan juga tidak berhubungan dengan produk fisik.

Berdasarkan riset dan literatur pemasaran jasa mengungkapkan bahwa jasa memiliki sejumlah karakteristik unik yang membedakan dari barang dan berdampak pada cara memasarkannya. Menurut (Tiptono, 2005) jasa terdiri atas lima karakteristik yaitu:

a. Intagibility (tidak berwujud) yaitu jasa tidak dapat dirasakan, dilihat, diraba, dicium, atau didengar sebelum ada transaksi pembelian. Bila konsumen membeli jasa maka ia hanya menggunakan, memanfaatkan, atau menyewa jasa tersebut

b. Inseparability (tidak terpisahkan) yaitu jasa tidak dapat dipisahkan dari sumber pemberinya. Pemberian jasa membutuhkan kehadiran pemberi jasa baik berupa seorang manusia atau mesin. Produksi dan konsumsi terjadi bersama - sama dengan pemberi jasa

c. Variability (bervariasi) yaitu jasa bersifat sangat variabel karena merupakan non standardized output artinya banyak sekali variasi bentuk, kualitas dan jenis, tergantung siapa, kapan dan dimana jasa tersebut dihasilkan

d. Perishability (mudah lenyap) yaitu jasa merupakan komoditi yang tidak tahan lama dan merupakan komoditi yang tidak dapat disimpan.

e. Lack of ownership (kurangnya rasa kepemilikan) merupakan perbedaan dasar antara jasa dan barang. Jasa Tidak dimiliki oleh konsumnennya atau dengan kata lain jasa disewakan.

Kulitas jasa adalah tingkat keunggulan yang diharapkan dan pengendalian atas tingkat keunggulan tersebut anak memenuhi keinginan pelanggan. Menurut (Tiptono, 2005) kualitas suatu jasa yang dipersiapkan pelanggan terdiri atas dua dimensi utama yaitu dimensi technical quality dan dimensi functional quality.

Menurut (Supranto, 2004), kualitas adalah sebuah kata yang bagi penyedia jasa merupakan suatu yang harus dikerjakan dengan baik. Kualitas jasa atau kualitas layanan (service quality) berkontribusi signifikan bagi penciptaan diferensiasi, positioning dan strategi bersaing setiap organisasi pemasaran, baik manufaktur maupun penyedia jasa. Keunggulan suatu produk jasa adalah tergantung dari keunikan serta kualitas yang diperlihatkan oleh jasa tersebut, apakah sudah sesuai dengan harapan dan keinginan konsumen. Harapan pelanggan dibentuk oleh pengalaman masa lalunya, kemudian membandingkannya.

Pengukuran kualitas jasa dalam model servqual didasarkan pada skala multi item yang dirancang untuk mengukur harapan dan persepsi pelanggan dalam dimensi-dimensi kualitas jasa. Menurut (Tiptono, 2005) terdapat lima dimensi utama kualitas jasa sebagai berikut.

a. Daya tanggap (responsiveness), yaitu suatu kebijakan untuk membantu dan memberikan pelayanan yang cepat (responsif) dan tepat kepada pelanggan, dengan penyampaian informasi yang jelas.

b. Keandalan (reliability), yaitu kemampuan perusahaan jasa untuk memberikan 
pelayanan sesuai dengan yang dijanjikan secara akurat dan tepercaya. Kinerja harus sesuai dengan harapan pelanggan yang berarti ketepatan waktu, pelayanan yang sama untuk semua pelanggan tanpa kesalahan, sikap yang simpatik, dan dengan akurasi yang tinggi.

c. Jaminan (assurance), yaitu pengetahuan, kesopan santunan, dan kemampuan para karyawan perusahaan jasa untuk menumbuhkan rasa percaya para pelanggan kepada perusahaan. Hal ini meliputi beberapa komponen antara lain komunikasi (communication), kredibilitas (credibility), keamanan (security), kompetensi (competence), dan sopan santun (courtesy).

d. Empati (empathy), yaitu memberikan perhatian yang tulus dan bersifat individual atau pribadi yang diberikan kepada para pelanggan dengan berupaya memahami keinginan pelanggan. Di mana suatu perusahaan jasa diharapkan memiliki pengertian dan pengetahuan tentang pelanggan, memahami kebutuhan pelanggan secara spesifik, serta memiliki waktu pengoperasian yang nyaman bagi pelanggan.

e. Bukti fisik (tangible), yaitu kemampuan suatu perusahaan dalam menunjukkan eksistensinya kepada pihak eksternal. Penampilan dan kemampuan sarana dan prasarana fisik perusahaan jasa yang dapat diandalkan keadaan lingkungan sekitarnya merupakan bukti nyata dan pelayanan yang diberikan oleh pemberi jasa. Hal ini meliputi fasilitas fisik, perlengkapan dan paralatan yang digunakan, serta penampilan pegawainya.

Pengertian kepuasan pelanggan menurut (Tiptono, 2005) adalah tanggapan emosional pada evaluasi terhadap pengamatan konsumsi suatu produk atau jasa. Sedangkan pengertian kepuasan pelanggan menurut Mowen dalam (Tiptono, 2005) merumuskan pelanggan sebagai sikap keseluruhan terhadap suatu barang atau jasa setelah perolehan dan pemakaiannya. Dengan kata lain, kepuasan pelanggan merupakan penilaian purna beli yang dihasilkan dari seleksi pembelian spesifik. Sehingga pada dasamya tujuan sebuah bisnis adalah menciptakan para pelanggan yang puas. Pencapaian kepuasan bisa dikatakan merupakan proses yang sederhana, maupun kompleks dan rumit. Dalam hal ini peranan setiap individu dalam service encoounter sangatlah penting dan berpengaruh terhadap kepuasan yang dibentuk.

Menurut (Tjiptono, 2007) kepuasan pelanggan adalah tingkat perasaan seseorang setelah membandingkan kinerja (atau hasil) yang ia rasakan dibandingkan dengan harapannya. Ada beberapa rnetode yang dapat dipergunakan setiap perusahaan untuk mengukur dan memantau kepuasan pelanggannya. Empat metode untuk mengukur kepuasan pelanggan yaitu.

a. Sistem keluhan dan saran, perusahaan memberikan kesempatan seluas-luasnya kepada pelanggannya untuk menyampaikan saran, kritik, pendapat, serta keluhan mereka.

b. Ghost Shopping, perusahaan mempekerjakan beberapa orang (ghost shopper) untuk berperan atau bersikap sebagai pelanggan atau pembeli potensial produk perusahaan dan pesaing. Orang tersebut kemungkinan menyampaikan temuantemuannya mengenai kekuatan dan kelemahan produk perusahaan dan pesaing berdasarkan pengalaman mereka dalam pembelian produk-produk tersebut.

c. Lost customer analysis, perusahaan menghubungi pelanggan atau pembeli 
yang telah berhenti membeli atau yang telah beralih pemasok agar dapat memahami mengapa hal tersebut terjadi dan agar dapat mengambil kebijakan perbaikan atau penyempurnaan selanjutnya.

d. Survei Kepuasan Pelanggan, perusahaan melakukan survei untuk memperoleh tanggapan dan umpan balik langsung dari pelanggan dan juga memberikan sinyal positif bahwa perusahaan menaruh perhatian terhadap pelanggannya.

Menurut (Tiptono, 2005) loyalitas pelanggan adalah komitmen pelanggan terhadap suatu merek, toko, atau pemasok, berdasarkan sikap yang sangat positif dan tercermin dalam pembelian ulang yang konsisten. Loyalitas pelanggan dalam konteks pemasaran jasa adalah respons yang terkait erat dengan ikrar atau janji untuk memegang teguh komitmen yang mendasari kontinuitas relasi, dan biasanya tercermin dalam pembelian berkelanjutan dari penyedia jasa yang sama atas dasar dedikasi maupun kendala pragmatis. Menurut (Tiptono, 2005) terdapat empat macam kemungkinan hubungan antara kepuasan dan loyalitas pelanggan yaitu failures (tidak puas dan tidak loyal), forced loyalty (tidak puas dan terikat promosi loyalitas), defectors (puas tapi tidak loyal), dan successes (puas dan loyal).

\section{Hipotesis dalam penelitian ini :}

a. Diduga variabel daya tanggap, keandalan, jaminan, Empati, dan bukti fisik secara simultan dan parsial berpengaruh signifikan terhadap kepuasan anggota perpustakaan di STIE Mandala Jember.

b. Diduga variabel bukti fisik memiliki pengaruh paling dominan terhadap kepuasan anggota perpustakaan di STIE Mandala Jember.

\section{METODE PENELITIAN}

Menurut (Tiptono, 2005) populasi adalah wilayah generalisasi yang terdiri atas obyek/subyek yang mempunyai karakteristik tertentu yang ditetapkan oleh peneliti untuk dipelajari dan kemudian ditarik kesimpulan. Populasi dalam penelitian ini adalah mahasiswa aktif STIE Mandala Jember angkatan 2014 sampai 2017 yang masih aktif sampai tahun 2018 dan dirasa sudah pernah menerima pelayanan dari bidang perpustakaan.

Sampel adalah sebagian dari populasi, sampel terdiri atas sejumlah anggota yang dipilih dari populasi, sampling memberikan pedoman penentuan besarnya sampel penelitian, yaitu: jumlah sampel lebih besar dari 30 dan lebih kecil dari 500 telah mencukupi untuk semua penelitian. Dalam penelitian ini menggunakan sampel sebanyak 40 orang responden mahasiswa aktif angkatan 2014, 2015, 2016 dan 2017 dengan Teknik pengambilan sampel (sampling) menggunakan Random Sampling

Analisis data merupakan salah satu cara yang digunakan untuk mengetahui sejauh mana variabel yang mempengaruhi variabel yang lain agar data yang dikumpulkan tersebut dapat bermanfaat maka harus diolah / dianalisis terlebih dahulu sehingga dapat dijadikan dasar dalam mengambil keputusan. Analisis yang digunakan dalam penelitian ini adalah Analisis Regresi Linier Berganda, adapun rumus dasarnya adalah sebagai berikut: 


$$
\mathrm{Y}=\mathrm{a}+\mathrm{b}_{1} \mathrm{X}_{1}+\mathrm{b}_{2} \mathrm{X}_{2}+\mathrm{b}_{3} \mathrm{X}_{3}+\mathrm{b}_{4} \mathrm{X}_{4}+\mathrm{b}_{5} \mathrm{X}_{5}+e
$$

Dimana:

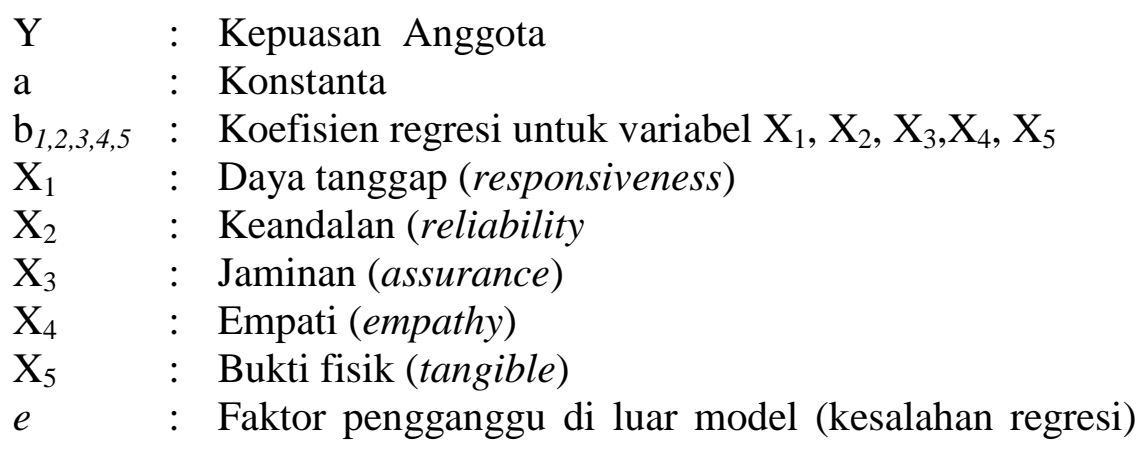

\section{Uji Asumsi Klasik}

\section{a. Uji Normalitas (Normality)}

Data yang baik dan layak untuk membuktikan model-model penelitian adalah data yang memiliki distribusi normal. Uji normalitas di lakukan dengan One-Sample Kolmogorov-Smirnov Testdan Shapiro Wilk, normal probability plot dengan bantuan program statistik komputer IBM SPSS (Statistic Packet For Social Science) versi 20.00 (Ghozali, 2013,p.81).

b. Uji Multikolinearitas

Suatu model regresi dikatakan bebas dari multikolinearitas jika mempunyai nilai VIF disekitar angka 1 dan mempunyai angka tolerance mendekati 1 . Dimana, tolerance $=1 /$ VIF atau VIF $=1$ /tolerance (Ghozali, 2013, p. 84).

\section{c. Uji Heterokedastisitas}

Untuk mendeteksi adanya Heterokedastisitas dapat dilakukan dengan menggunakan Sactter Plot. Apabila tidak terdapat pola yang teratur, maka model regresi tersebut bebas dari masalah heteroskedastisitas. Menguji apakah dalam suatu model regresi terjadi ketidaksamaan varian dari residual antara satu pengamatan ke pengamatan lain. Jika varian dari residual satu pengamatan ke pengamatan lain tetap, maka dikatakan homoskedastisitas. Apabila varian tidak sama, disebut heteroskedastisitas (Ghozali, 2013, p. 87).

\section{Uji Hipotesis}

\section{a. $\quad \mathbf{U j i} \mathbf{F}$}

Uji statistik $\mathrm{F}$ pada dasarnya menunjukkan apakah semua variabel independen atau bebas yang dimasukkan dalam model mempunyai pengaruh secara bersama-sama terhadap variabel dependen/terikat.

a) $\mathrm{H}_{0}=0$, artinya tidak ada pengaruh yang signifikan dan positif dari variabel independen secara simultan terhadap variabel dependen. 
b) $\mathrm{H}_{1} \neq 0$, artinya ada pengaruh signifikan dan positif antara variabel independen secara simultan terhadap variabel dependen (Kepuasan Anggota).

Untuk menguji hipotesis digunakan statistik $\mathrm{F}$ dengan krieria pengambilan keputusan sebagai berikut :

a) Quick look: bila nilai F lebih besar daripada 4 maka $\mathrm{H}_{0}$ dapat ditolak pada derajat kepercayaan 5\%. Dengan kata lain kita menerima hipotesis alternatif, yang menyatakan bahwa semua variable independen secar serentak signifikan dan positif mempengaruhi variable dependen.

b) Membandingkan nilai $\mathrm{F}$ hasil perhitungan dengan nilai $\mathrm{F}$ menurut tabel. Bila nilai $\mathrm{F}_{\text {hitung }}$ lebih besar daripada nilai $\mathrm{F}_{\text {tabel}}$, maka $\mathrm{H}_{0}$ ditolak dan menerima $\mathrm{H}_{1}$ (Ghozali, 2013, p. 96).

\section{b. Uji t}

Pengujian ini dilakukan untuk mengetahui apakah variabel independen secara individu berpengaruh terhadap variabel dependen. Adapun ketentuan penerimaan atau penolakan apabila angka signifikan di bawah atau sama dengan 0,05 maka $\mathrm{H}_{1}$ diterima dan $\mathrm{H}_{0}$ ditolak.

Pengujian hipotetis juga dapat menggunakan perbandingan antara $t$ hitung dengan $t$ tabel dengan ketentuan:

a) $\mathrm{H}_{0}: \beta_{i}=0$, berarti secara parsial tidak terdapat pengaruh yang signifikan dan positif dari variabel independen terhadap variabel dependen.

b) $\mathrm{H}_{1}: \beta_{i} \neq 0$, berarti secara parsial terdapat pengaruh yang signifikan dan positif dari variabel independen terhadap variabel dependen (Ghozali, 2013, p. 100).

\section{Analisis Koefisien Determinasi $\left(\mathbf{R}^{2}\right)$}

Koefisien determinasi $\left(\mathrm{R}^{2}\right)$ pada intinya mengukur seberapa jauh kemampuan model dalam menerangkan variasi variabel terikat. Nilai koefisien determinasi adalah antara nol dan satu. Nilai $\left(\mathrm{R}^{2}\right)$ yang kecil berarti kemampuan variabel-variabel bebas (Daya tanggap, Keandalan, Jaminan, Empati dan Bukti Fisik) dalam menjelaskan variasi variabel terikat (Kepuasan Anggota) amat terbatas. Begitu pula sebaliknya, nilai yang mendekati satu berarti variabelvariabel bebas memberikan hampir semua informasi yang di butuhkan untuk memeprediksi variasi variabel terikat (Ghozali, 2013, p. 109).

\section{HASIL DAN PEMBAHASAN}

Uji validitas dilakukan untuk mengetahui sampai sejauh mana suatu kuesioner yang diajukan dapat menggali data atau informasi yang diperlukan. Hasil uji validitas dikatakan valid jika $r_{\text {hitung }}$ minimal 0,3 . Hasil pengujian validitas kuesioner atas 6 (enam) variabel dalam penelitian ini menunjukkan bahwa semua 
item pertanyaan pada masing-masing variabel $\mathrm{r}_{\text {hitung }}>0,3$ dengan tingkat signifikansi dibawah 5\%, maka dapat disimpulkan bahwa kuesioner yang digunakan untuk menggali data adalah valid.

Uji reliabilitas dilakukan untuk mengukur sampai sejauh mana kuesioner yang diajukan dapat memberikan hasil yang tidak berbeda dengan menggunakan rumus Cronbach Alpha. Hasil pengujian reliabilitas kuesioner atas 6 (enam) variabel dalam penelitian ini menunjukkan bahwa 6 (enam) variabel mempunyai nilai Cronbach Alpha diatas 0,6 yang berarti reliabel. Jadi dapat disimpulkan semua konsep pengukur masing-masing variabel dari kuesioner yang digunakan dalam penelitian ini merupakan kuesioner yang handal.

\section{Hasil Uji Asumsi Dasar Regresi Linear Berganda}

Pengujian normalitas dilakukan terhadap residual regresi. Pengujian dilakukan dengan menggunakan grafik P-P Plot. Data yang normal adalah data yang membentuk titik-titik yang menyebar tidak jauh dari garis diagonal, jika nilai-nilai sebaran data terletak disekitar garis lurus diagonal maka persyaratan normalitas terpenuhi.

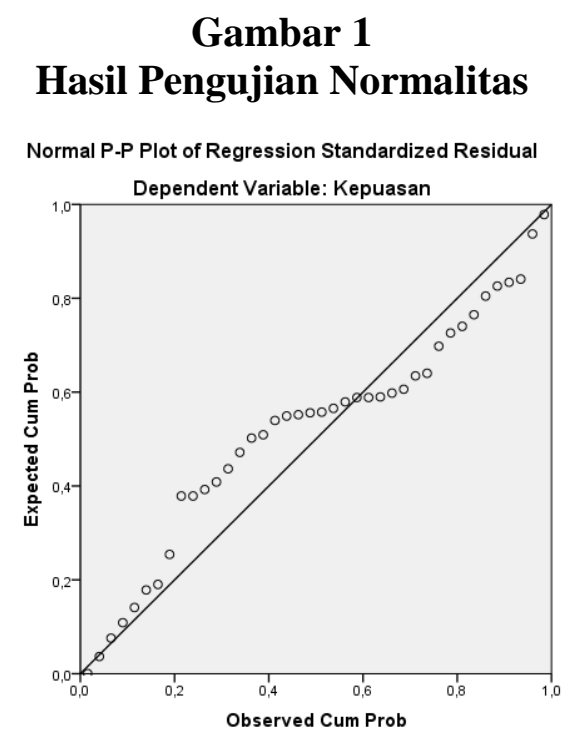

Sumber: Hasil Pengolahan Data Kuesioner dengan SPSS

Hasil pengujian normalitas data menunjukkan adanya pola grafik yang normal dimana titik-titik berada tidak jauh dari garis diagonal, hal ini berarti bahwa model regresi tersebut sudah berdistribusi normal.

Suatu variabel menunjukkan gejala multikolinearitas bisa dilihat dari nilai VIF (Variance Inflation Factor) yang tinggi pada variabel-variabel bebas suatu model regresi. Nilai VIF yang lebih besar dari 10 menunjukkan adanya gejala multikolinearitas dalam model regresi (Sugiyono, 2005, p. 139). Jadi untuk suatu data dikatakan bebas dari multikolinearitas jika nilai VIF berada dibawah 10 . Hasil penelitian menunjukkan bahwa semua variabel yang digunakan sebagai prediktor model regresi menunjukkan nilai VIF yang cukup kecil, dimana semuanya berada di bawah 10 dan nilai Tollerance lebih dari 0,1 . Hal ini berarti 
bahwa variabel bebas yang digunakan dalam penelitian tidak menunjukkan gejala multikolinearitas.

\section{Hasil Uji Heteroskedastisitas}

Pengujian heteroskedastisitas dilakukan dengan menggunakan Scatter Plot. Jika tidak terdapat variabel yang signifikan maka dapat disimpulkan tidak adanya masalah heteroskedastisitas. Hasil pengujian berikut ini:

Gambar 2

Hasil Heteroskedastisitas

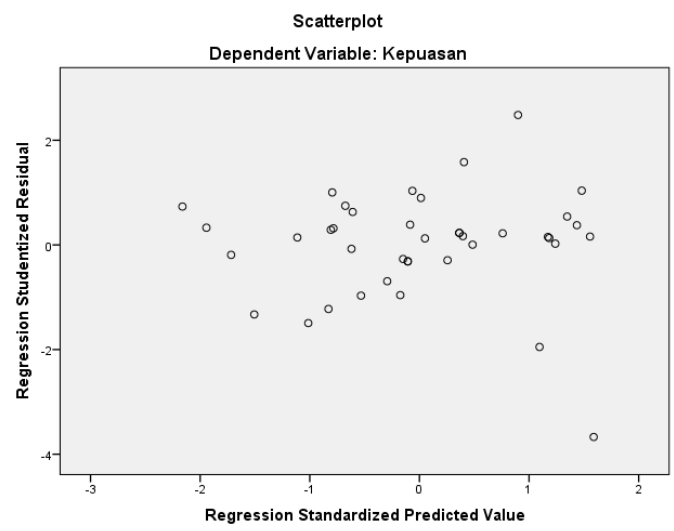

Sumber : Hasil Pengolahan Data Kuesioner dengan SPSS

Hasil pengujian heteroskedastisitas menunjukkan tidak terdapat pola yang jelas dari titik-titik tersebut. Hal ini menunjukkan bahwa model regresi tidak memiliki gejala adanya heteroskedastisitas, yang berarti bahwa tidak ada gangguan yang berarti dalam model regresi ini. Berdasarkan hasil olah SPSS 20.0, diperoleh hasil sebagai berikut: 
Tabel 1

Regresi Linear Berganda

Coefficients $^{\mathrm{a}}$

\begin{tabular}{|c|c|c|c|c|c|c|c|}
\hline \multirow[t]{2}{*}{ Model } & \multicolumn{2}{|c|}{$\begin{array}{l}\text { Unstandardized } \\
\text { Coefficients }\end{array}$} & \multirow{2}{*}{$\begin{array}{c}\begin{array}{c}\text { Standardized } \\
\text { Coefficients }\end{array} \\
\text { Beta }\end{array}$} & \multirow[t]{2}{*}{$\mathrm{T}$} & \multirow[t]{2}{*}{ Sig. } & \multicolumn{2}{|c|}{$\begin{array}{l}\text { Collinearity } \\
\text { Statistics }\end{array}$} \\
\hline & B & Std. Error & & & & Tolerance & VIF \\
\hline (Constant) &,- 627 & 600 & & $-1,046$ & ,303 & & \\
\hline Daya Tanggap & 237 &, 150 & , 169 & 1,698 &, 023 &, 542 & 1,844 \\
\hline Keandalan &,- 151 &, 170 &,- 108 &,- 888 & ,381 & 420 & 2,378 \\
\hline Jaminan &, 085 &, 174 &, 052 & ,491 &, 627 &, 543 & 1,842 \\
\hline Empati & 071 &, 101 & ,066 & ,704 & ,486 & ,703 & 1,422 \\
\hline Bukti Fisik & ,895 &, 118 &, 783 & 7,590 &, 000 &, 582 & 1,719 \\
\hline
\end{tabular}

Model persamaan regresi yang dapat dituliskan dari hasil tersebut dalam bentuk persamaan regresi Unstandardized coefficien adalah sebagai berikut :

$$
\mathrm{Y}=-0,627+0,237 \mathrm{X}_{1}-0,151 \mathrm{X}_{2}+0,085 \mathrm{X}_{3}+0,071 \mathrm{X}_{4}+0,895 \mathrm{X}_{5}
$$

Dari hasil persamaan regresi linier berganda tersebut dapat dijelaskan sebagai berikut:

a. Koefisien daya tanggap sebesar 0,237, menyatakan bahwa setiap kenaikan 1 (satu) nilai daya tanggap akan menurunkan kepuasan sebesar 0,237 dan sebaliknya setiap penurunan (satu) nilai daya tanggap akan menaikkan kepuasan sebesar 0,273 dengan asumsi variabel independen lainnya konstan atau tetap.

b. Koefisien keandalan sebesar $-0,151$, menyatakan bahwa setiap kenaikan 1 (satu) nilai keandalan akan menaikkan kepuasan sebesar -0,151 dan sebaliknya setiap penurunan 1 (satu) nilai keandalan akan menurunkan kepuasan sebesar -0,151, dengan asumsi variabel independen lainnya konstan atau tetap.

c. Koefisien jaminan sebesar 0,085 , menyatakan bahwa setiap kenaikan 1 (satu) nilai jaminan akan menurunkan kepuasan sebesar 0,085 dan sebaliknya setiap penurunan 1 (satu) nilai jaminan akan menaikkan kepuasan sebesar 0,085, dengan asumsi variabel independen lainnya konstan atau tetap.

d. Koefisien Empati sebesar 0,071, menyatakan bahwa setiap kenaikan 1 (satu) nilai Empati akan menurunkan kepuasan sebesar 0,071 dan sebaliknya setiap penurunan 1 (satu) nilai Empati akan menaikkan kepuasan sebesar 0,071, dengan asumsi variabel independen lainnya konstan atau tetap.

e. Koefisien bukti fisik sebesar 0,895, menyatakan bahwa setiap kenaikan 1 (satu) nilai bukti fisik akan menurunkan kepuasan sebesar 0,895 dan sebaliknya setiap penurunan 1 (satu) nilai jaminan akan menaikkan 
kepuasan sebesar 0,895, dengan asumsi variabel independen lainnya konstan atau tetap.

Berdasarkan tabel di atas, diketahui bahwa variable independen yang paling berpengaruh terhadap kepuasan adalah variable bukti fisik dengan koefisien 0,895 .

\section{Pengujian Hipotesis Penelitian}

Pengujian hipotesis secara parsial atau individu untuk masing-masing variabel melalui pengujian model substruktur kedua sebagai berikut :

\section{Tabel 2}

Uji t (Uji Parsial)

Coefficients $^{\mathrm{a}}$

\begin{tabular}{lccccccc}
\hline Model & \multicolumn{2}{c}{$\begin{array}{c}\text { Unstandardized } \\
\text { Coefficients }\end{array}$} & $\begin{array}{c}\text { Standardized } \\
\text { Coefficients }\end{array}$ & $\mathrm{t}$ & Sig. & \multicolumn{2}{c}{ Collinearity } \\
& $\mathrm{B}$ & Std. Error & Beta & & & \multicolumn{2}{c}{ Statistics } \\
Tolerance & VIF \\
\hline (Constant) &,- 627 &, 600 & &,- 046 &, 303 & & \\
Daya Tanggap &, 237 &, 150 &, 169 & 1,698 &, 023 &, 542 & 1,844 \\
Keandalan &,- 151 &, 170 &,- 108 &,- 888 &, 381 &, 420 & 2,378 \\
Jaminan &, 085 &, 174 &, 052 &, 491 &, 627 &, 543 & 1,842 \\
Empati &, 071 &, 101 &, 066 &, 704 &, 486 &, 703 & 1,422 \\
Bukti Fisik &, 895 &, 118 &, 783 & 7,590 &, 000 &, 582 & 1,719 \\
\hline
\end{tabular}

a. Dependent Variable: Kepuasan

1. Variabel Daya Tanggap terhadap Kepuasan Anggota.

Hasil uji $t$ untuk daya tanggap menunjukkan tingkat signifikansi sebesar $0,023<\alpha_{(0,05)}$ maka hipotesis diterima dan disimpulkan variabel daya tanggap berpengaruh terhadap kepuasan anggota. Variabel daya tanggap pada penelitian ini memiliki tiga indikator yakni kecepatan dalam memberikan layanan, ketrampilan karyawan dalam menanggapi kebutuhan anggota perpustakaan serta kesigapan karyawan dalam menanggapi setiap kebutuhan anggota perpustakaan. Dari hasil survey yang telah peneliti lakukan dapat dilihat bahwa anggota perpustakaan khususnya dalam penelitian ini adalah mahasiswa menyatakan setuju bahwa karyawan perpustakaan telah memiliki daya tanggap yang baik dalam memberikan pelayanan terhadap anggotanya, sehingga mahasiswa merasa puas dengan layanan yang mereka dapatkan.

2. Variabel Keandalan terhadap Kepuasan Anggota.

Hasil uji t Keandalan menunjukkan tingkat signifikansi sebesar $(0,381)>$ $\alpha_{(0,05)}$ maka hipotesis ditolak dan disimpulkan variabel keandalan tidak berpengaruh terhadap kepuasan anggota. Variabel keandalan yang terdiri dari tiga indikator yakni keandalan dalam menangani problem pelayanan bagi pengguna perpustakaan, pelayanan jasa pada waktu yang dijanjikan, ketepatan waktu layanan sesuai jam kerja dari lembaga tidak berpengaruh terhadap kepuasan anggota perpustakaan, hal ini berarti keandalan yang dilakukan oleh karyawan perpustakaan tidak mampu meningkatkan kepuasan anggotanya. Pada indikator 
pertanyaan yang diberikan responden anggota perpustakaan menganggap bahwa kemampuan dan kualitas layanan yang diberikan oleh karyawan perpustakaan kurang sesuai dengan apa yang diharapkan oleh para anggota perpustakaan. Penilaian anggota perpustakaan terhadap karyawan dikarenakan karyawan yang bertugas diperpustakaan kurang memiliki kompetensi yang sesuai dengan keahliannya.

\section{Variabel Jaminan terhadap Kepuasan Anggota.}

Hasil uji t Jaminan menunjukkan tingkat signifikansi sebesar $(0,627)>$ $\alpha_{(0,05)}$ maka hipotesis ditolak dan disimpulkan variabel jaminan tidak berpengaruh terhadap kepuasan anggota. Variabel keterjaminan yang terdiri dari empat indikator yakni pelayanan sesuai dengan prosedur yang benar, menanamkan kepercayaan kepada pengguna jasa/memberikan kebebasan terhadap anggota perpustakaan untuk mendapatkan buku yang diinginkan, pengetahuan luas untuk menjawab pertanyaan pengguna jasa, sikap ramah tamah terhadap pengguna jasa perpustakaan, tidak berpengaruh terhadap kepuasan anggota perpustakaan, hal ini berarti keterjaminan yang dilakukan oleh karyawan perpustakaan belum mampu meningkatkan kepuasan anggotanya. Pada indikator pertanyaan yang diberikan, responden anggota perpustakaan menganggap bahwa kemampuan dan kualitas layanan yang diberikan oleh karyawan perpustakaan kurang sesuai dengan apa yang diharapkan oleh para anggota perpustakaan. Penilaian anggota perpustakaan terhadap karyawan dikarenakan karyawan yang bertugas diperpustakaan kurang memiliki pengetahuan yang luas untuk menjawab pertanyaan anggotanya, sikap kurang ramah yang diberikan oleh karyawan perpustakaan membuat anggota perpustakaan khususnya dalam penelitian ini adalah mahasiswa aktif kurang memberikan kepuasan terhadap anggota perpustakaan, oleh karena itu dari pihak lembaga hendaknya memberikan pelatihan berkelanjutan kepada karyawan perpustakaan mengenai bagaimana cara memberika pelayanan yang baik kepada pengguna jasa.

\section{Variabel Empati terhadap Kepuasan Anggota.}

Hasil uji t Empati menunjukkan tingkat signifikansi sebesar $(0,486)>\alpha_{(0,05)}$ maka hipotesis ditolak dan disimpulkan variabel Empati tidak berpengaruh terhadap kepuasan anggota. Variabel Empati yang terdiri dari dua indikator yakni kemampuan karyawan dalam berkomunikasi dengan pengguna jasa serta kejelasan karyawan dalam memberikan informasi kepada pengguna jasa, memahami kebutuhan dan keinginan pengguna jasa, tidak berpengaruh terhadap kepuasan anggota perpustakaan, hal ini berarti variabel Empati yang dilakukan oleh karyawan perpustakaan belum mampu meningkatkan kepuasan anggotanya. Penilaian anggota perpustakaan terhadap karyawan dikarenakan karyawan yang bertugas diperpustakaan kurang memiliki kemampuan berkomunikasi secara baik dengan pengguna jasa perpustakaan, anggota perpustakaan kurang mendapatkan informasi dari karyawan yang ada di perpustakaan, sehingga mereka tidak memahami akan kebutuhan dan keiinginan pengguna jasa, hal ini mungkin disebabkan karena petugas yang ada diperpustakaan terbatas hanya 2 orang staf saja, serta kedua orang staf tersebut tidak memiliki kompetensi di bidang 
perpustakaan, oleh karena itu pihak lembaga hendaknya mengikut sertakan berbagi macam pelatihan, workshop mengenai layanan perpustakaan bagi karyawan di perpustakaan.

5. Variabel Bukti Fisik terhadap Kepuasan Anggota.

Hasil uji t Bukti Fisik menunjukkan tingkat signifikansi sebesar $(0,00)<$ $\alpha_{(0,05)}$ maka hipotesis diterima dan disimpulkan bukti fisik berpengaruh terhadap kepuasan anggota. Variabel bukti fisik yang terdiri dari lima indikator yakni sarana, prasarana, kelengkapan, koleksi buku dan kerapian atau cara berpakaian karyawan di perpustakaan berpengaruh secara signifikan terhadap kepuasan anggota perpustakaan. Dari hasil survey yang telah peneliti lakukan dapat dilihat bahwa anggota perpustakaan khususnya dalam penelitian ini adalah mahasiswa menyatakan setuju bahwa bukti fisik telah memberikan kepuasan terhadap anggota perputakaan, dari fasilitas yang semakin hari semakin baik seperti pemberian $\mathrm{AC}$, sehingga anggota perpustakaan merasa nyaman berada di dalam ruang perpustakaan, selain itu koleksi buku dan judul buku yang semakin hari semakin bertambah sehingga dapat memenuhi kebutuhan anggota perpustakaan.

Berdasarkan hasil SPSS 20, maka diperoleh hasil uji F (Uji Simultan) sebagai berikut :

\section{Tabel 3}

Uji F (Uji Simultan)

ANOVA $^{a}$

\begin{tabular}{lccccc}
\hline Model & Sum of Squares & df & Mean Square & F & Sig. \\
\hline Regression & 16,684 & 5 & 3,337 & 25,555 &, $000^{\mathrm{b}}$ \\
Residual & 4,439 & 34 &, 131 & & \\
Total & 21,123 & 39 & & & \\
\hline
\end{tabular}

a. Dependent Variable: Kepuasan

b. Predictors: (Constant), Bukti Fisik, Empati, Jaminan, Daya Tanggap, Keandalan Sumber : Hasil Pengolahan Data Kuesioner dengan SPSS

$\mathrm{H}_{2}=$ Daya Tanggap, Keandalan, Jaminan, Empati, dan Bukti Fisik berpengaruh positif signifikan secara simultan terhadap kepuasan anggota.

Berdasarkan Tabel 3 diperoleh nilai $\mathrm{F}_{\text {hitung }}$ sebesar 25,555 dan tingkat signifikan 0,000 , dengan tingkat signifikan $(0,000)<\alpha_{(0,05)}$ maka hipotesis diterima dan disimpulkan terdapat pengaruh secara Simultan (Daya Tanggap, Jaminan, Empati, dan Bukti Fisik) terhadap kepuasan anggota.

\section{Koefisien Determinasi}

Berdasarkan hasil SPSS 20, maka diperoleh hasil sebagai berikut: 


\section{Tabel 4}

Koefisien Determinasi

Model Summary ${ }^{b}$

\begin{tabular}{|c|c|c|c|c|}
\hline Model & $\mathrm{R}$ & R Square & Adjusted R Square & Std. Error of the Estimate \\
\hline 1 &, $889^{\mathrm{a}}$ &, 790 &, 759 &, 36135 \\
\hline
\end{tabular}

a. Predictors: (Constant), Bukti Fisik, Empati, Jaminan, Daya Tanggap, Keandalan

b. Dependent Variable: Kepuasan

Sumber : Hasil Pengolahan Data Kuesioner dengan SPSS

Nilai Adjusted $R$ Square sebesar 0,759. Hal ini berarti $76 \%$ kepuasan anggota perpustakaan dapat dijelaskan oleh variabel daya tanggap, keandalan, jaminan, Empati, dan bukti fisik. Sedangkan sisanya yaitu $24 \%$ kepuasan anggota perpustakaan dipengaruhi oleh variabel-variabel lainnya yang tidak diteliti dalam penelitian ini.

\section{E. SIMPULAN}

Dari hasil analisis data dan pembahasan yang telah dikemukakan dalam penelitian ini, maka dapat diambil beberapa kesimpulan antara lain sebagai berikut :

1. Terdapat pengaruh yang signifikan variabel daya tanggap, keandalan, jaminan, Empati, dan bukti fisik (secara simultan) terhadap kepuasan anggota perpustakaan di STIE Mandala Jember.

2. Terdapat pengaruh yang signifikan variabel daya tanggap terhadap kepuasan anggota perpustakaan di STIE Mandala Jember.

3. Tidak terdapat pengaruh yang signifikan variabel keandalan terhadap kepuasan anggota perpustakaan di STIE Mandala Jember.

4. Tidak terdapat pengaruh yang signifikan variabel jaminan terhadap kepuasan anggota perpustakaan di STIE Mandala Jember

5. Tidak terdapat pengaruh yang signifikan variabel Empati terhadap kepuasan anggota perpustakaan di STIE Mandala Jember.

6. Terdapat pengaruh yang signifikan variabel bukti fisik terhadap kepuasan anggota perpustakaan di STIE Mandala Jember.

7. Variabel yang berpengaruh paling dominan dari penelitian ini adalah bukti fisik dengan ditunjukkan oleh nilai t hitung sebesar 7,590. 


\section{DAFTAR PUSTAKA}

Ghozali, I. (2013). Aplikasi Analisis Multivariate dengan Program SPSS. Semarang, Jawa Tengah, Indonesia: Badan Penerbit Universitas Diponegoro.

Kotler, P. (1997). Manajemen Pemasaran: Analisis, Perencanaan, Implementasi, dan Kontrol (Vol. 1). Jakarta, DKI Jakarta, Indonesia: PT. Prenhallindo.

Sugiyono. (2005). Metode Penelitian Bisnis (4 ed.). Bandung, Jawa Barat, Indonesia: CV. Alphabet.

Supranto, J. (2004). Pengukuran Tingkat Kepuasan Pelanggan untuk Menaikkan Pangsa Pasar. Jakarta, DKI Jakarta, Indonesia: Rineka Cipta.

Sutarno, S. N. (2006). Manajemen Perpustakaan: Suatu Pendekatan Praktik. Jakarta, DKI Jakarta, Indonesia: Sagung Seto.

Tjiptono, E. (2005). Pemasaran Jasa (1 ed.). Yogyakarta, Jawa Tengah, Indonesia: Penerbit Andi.

Tjiptono, E. (2007). Pemasaran Jasa. Malang, Jawa Tengah, Indonesia: Bayumedia Publishing. 